\title{
Synthesis, pharmacokinetics, and biological use of lysine-modified single-walled carbon nanotubes [Erratum]
}

Mulvey JJ, Feinberg EN, Alidori S, et al. Int J Nanomedicine.

2014;9:4245-4255.

On page 4249 the Supplementary materials statement should have included a hyperlink to the Supplementary materials. The link is included below:

http://www.dovepress.com/get supplementary file. php?f=79726.pdf

\section{Publish your work in this journal}

The International Journal of Nanomedicine is an international, peerreviewed journal focusing on the application of nanotechnology in diagnostics, therapeutics, and drug delivery systems throughout the biomedical field. This journal is indexed on PubMed Central, MedLine, CAS, SciSearch ${ }^{\circledR}$, Current Contents ${ }^{\circledR} /$ Clinical Medicine,
Journal Citation Reports/Science Edition, EMBase, Scopus and the Elsevier Bibliographic databases. The manuscript management system is completely online and includes a very quick and fair peer-review system, which is all easy to use. Visit http://www.dovepress.com/ testimonials.php to read real quotes from published authors. submit your manuscript $\mid$ www.dovepress.com

Dovepress

http://dx.doi.org// 0.2147/IJN.S79726 